Article

\title{
Mediating Structures in Sámi Language Revitalisation
}

\author{
Erika Sarivaara ${ }^{1}$ and Pigga Keskitalo ${ }^{2, *}$ \\ ${ }^{1}$ Department of Education, University of Lapland, 96101 Rovaniemi, Finland; E-Mail: erika.sarivaara@ulapland.fi \\ ${ }^{2}$ Teepee of Duodji and Livelihood, Sámi University College, 9520 Kautokeino, Norway; \\ E-Mail: pigga.keskitalo@samiskhs.no \\ * Corresponding author
}

Submitted: 2 June 2015 | Accepted: 15 November 2015 | Published: 15 February 2016

\begin{abstract}
The revitalisation of the Sámi languages and support for language domains are central educational measures in the post-assimilation situation in Northern Europe. Taking critical indigenous education as the starting point, this metatheoretical article discusses language revitalisation through mediating structures. Mediating structures provide the tools necessary to use language revitalisation as a means to counter the legacy of assimilation that has seriously affected the Sámi languages and caused language change. The article brings together recent research on the revitalisation of the Sámi languages. These studies are oriented towards the present situation of the Sámi languages and efforts to revive the languages. Relying on previous studies as well as new research, the article presents a communal model of language recovery, which facilitates an increase in the number of language speakers and also supports language domains. Such a mediating language revitalisation model builds social harmony in a postcolonial situation. The article emphasises the key tasks involved in the recovery of endangered languages.
\end{abstract}

\section{Keywords}

assimilation; language shift; mediating structures; revitalisation; Sámi education; Sámi people

Issue

This article is part of the issue "Educating Nomadic People", edited by Caroline Dyer (University of Leeds, UK).

(C) 2016 by the author(s); licensee Cogitatio (Lisbon, Portugal). This article is licensed under a Creative Commons Attribution 4.0 International License (CC BY).

\section{Introduction}

The Sámi people live in the north areas of Sweden, Finland, Norway and Russia's Kola Peninsula. They are recognised as indigenous peoples and thus protected under various international conventions guaranteeing the rights as indigenous peoples. There are approximately 100,000 Sámi depending on the definition criteria applied (Sarivaara, 2012). The Sámi were previously known as the Lappish, although this has now been replaced by the Sámi's own name, the Sámi people (sápmelaččat). According to current estimates, the Sámi languages developed, at the latest, during the second millennium BC. Moreover, during that period Sámi culture have seen to arise (Aikio, 2004, 2012). Sámi livelihoods traditionally base on nature. Hence originating from hunter-gather tribes, they have been involved in fishing, hunting, and semi-nomadic reindeer herding. However, currently about $10 \%$ of the Sámi are connected to reindeer herding (Solbakk, 2006).

The Sámi have experienced the phase of colonialism, which is a central manifestation of assimilation, and refers to the active merging of minorities into the mainstream population (see Battiste, 2000). Due to centuries of assimilationist policies and, policy measures, Sámi languages are endangered, and have lost partly their cultural and linguistic special features. Today, the Sámi have more or less embraced urbanisation, according to Finnish Sámi Parliament already 60\% of Sámi live outside Sámi homeland area. For example, in capital of Finland, Helsinki, lives around 1000 Sámi (Lindgren, 2000). Moreover, today the Sámi are part of the globalised world and its various cultural flows (Seurujärvi-Kari, 2012). 
This article problematizes the indigenous people group, the Sámi people, through the phenomenon of assimilation and the concept of revitalisation. Further, it looks at how mediating education could remedy the legacy of assimilation. The article is based on the researchers' extensive studies of assimilation, revitalisation and education in Norway and Finland (see e.g. Keskitalo, 2010; Keskitalo, Uusiautti, \& Määttä, 2013; Sarivaara, 2012, in press; Sarivaara \& Keskitalo, 2015). In addition to research work, they have long teaching experience both elementary and higher education levels, and thus have been able to follow and initiate the development of Sámi education. Both researchers have insider position due to research field, since besides the researcher experience; they have Sámi background, and are speakers of Sámi language. Erika Sarivaara has been working with project that aims to explore the Sámi identity, and level of assimilation and the revitalisation process within assimilated Sámi areas. Pigga Keskitalo has interviewed Sámi teachers and pupils, and has observed school education in Norway and Finland.

This article explores Sámi language revitalisation based on the mediating structures theory and, furthermore, explores the implementation of mediating structures within language revitalisation in Sámi core area. It stresses that revitalisation is an abstract zone, which will empower the Sámi people and the language environment. The article seeks, above all, to consider the limits of language revitalisation on the basis of mediating structures and Sámi education. Assimilation in this context is still little explored concept.

The article begins by discussing the assimilation processes in Sámi, which means the homeland area of Sámi people, in order to demonstrate how they have affected the Sámi people. The effects are broad and far-reaching, and vary from place to place and person to person. Furthermore, the concept of mediating and the educational models based on it are explored. Finally, the article analyses the challenges associated with revitalisation as well as the benefits of mediating actions.

\section{The Legacy of Assimilation}

In order to understand the current situation of the Sámi, it is necessary to look back at the long history of the assimilation processes. The demolition of such assimilationist processes is necessary to improve the Sámi language situation going forward. Assimilation has been followed by colonisation. According to Kuokkanen (2007), colonisation is based on ideologies and practices that were constructed during the Renaissance. At the universal level, the goal of colonization in many places has been to dominate the area and start exploiting the land and natural resources (Kuokkanen, 2007). Although the forms and intentions of colonisation have varied, the background aim has always been the exercise of power (Gilroy, 1993; Said, 1993; Spivak, 1985). Fanon (1959, 1961, 1952/1967) initiated a debate on how colonisation affects people's thoughts. In other words, he questioned the psychological effects of colonisation. However, the views on this issue vary from one researcher to another. One can say that colonisation has taken place in Sámiland on both psychological and practical levels because the Sámi have undergone psychological and cultural exploitation, their traditional lands have become settled, and their social and cultural structures have broken down (Kuokkanen, 1999; Lehtola, 2012; Minde, 2005). The colonisation process has long been a part of the governing authorities' attempts to assimilate the indigenous peoples into majority cultures.

As a consequence, the Sámi people have experienced a long history of assimilation, first as the result of church activates since the 1600 s and, second, due to the nation schools of the 1800 s (e.g. Keskitalo, Lehtola, \& Paksuniemi, 2014). However, the assimilation methods due to Sámi have varied from country to country. In Norway, the assimilation policy was formally constructed and the Sámi had to be "Norwegianized" (Norwegian fornorsking). This forced Norwegian period lasted from approximately the 1850 s to the 1980s. The aim was to eradicate the Sámi language and the Sámi identity (Minde, 2005). Sweden, meanwhile, utilised more passive segregation measures, namely the lappska-vara-lapp policy (The Lapp Should Stay Lapp policy), whereby Sámi children were sent to segregated hut schools (Henrysson, 1992). The situation of the Sámi in Russia has been challenging because Sami schooling has been supported to a limited extent. Additionally, forced relocations have stretched the capacity of the Russian Sámi (Afanasyeva, 2013). In Finland, assimilation has been more or less invisible when compared to, for example, the situation in Norway, where forced Norwegianism was enshrined in official documents. This can make it challenging to recognise and distinguish assimilation strategies and measures. In Finland, the nationalist policy aim was to strengthen the position of the Finnish language and the Finnish identity. The government prioritised the ideology of nation building and the needs of minorities were neglected until the 1960s, when the indigenous revival began. For example, in Finland, the assimilation era began in the 1600 s, and has not yet entirely stopped.

According to our studies and perceptions assimilation has thus inter alia somewhat weakened the Sámi cultural identity and started the process of language change. Such a process has resulted a complex situation that has also impacted on Sámi education. The revitalisation has taken place recently following lengthy periods of assimilation. The Sámi language and identity have become popular topics, particularly due to the improved situation. Some of the Sámi have built a strong cultural identity and indigenous community. 
However, some of the Sámi people have been disadvantaged due to their backgrounds and so assimilation has had a strong influence on them. The heritage of assimilation has contributed to equality between people. The Sámi identity was placed under close scrutiny when assimilated people started to become interested in the revitalisation of the Sámi languages and in their own roots and background. At the same time, debate has arisen in all communities regarding who should determine the mode of revitalisation and who should be allowed to participate in it. Thus, any discussion of the process of revitalisation seems also consider the vexed question of who exactly counts as a member of the Sámi community. (Sarivaara \& Keskitalo, 2015).

\section{From Language Shift to Revitalisation}

The "language shift" refers to a situation in which people stop using a language and instead make use of another, usually the language of the dominant culture. For example, people may cease to speak in their mother tongue language to their children and stop using it in other contexts or domains (e.g. Fishman, 1991; Linkola, 2014; Olthuis, Kivelä, \& Skutnabb-Kangas, 2013; Rasmussen, 2013). Such a language shift usually occurs in a situation where languages have an unequal status in society. In addition, inequality can follow as a result of assimilation policies. It is unlikely that a language shift will occur in societies that ascribe the same rights to the majority and the minority languages (Rasmussen, 2013). Ó Laoire (2008, p. 204) described language sociology as follows:

"Where language shift occurs in languages in contact situations, it usually reflects socio-political and socio-economic competitive tensions, conflicts and the struggle to establish a dominant cultural status between the different speech communities." (Ó Laoire, 2008, p. 204)

In Sámi context the level of language shift varies from place to place. Indeed, some traditional Sámi areas have experienced more intense assimilation compared to other part of Sámi regions. Assimilation managed to cause a language shift to a certain extent. For example, in some parts of the Norwegian Sámi coast and some areas of Finland a complete language shift occurred from Sámi languages to the majority language, so that some Sámi languages, for example Kemi Sámi, actually died out (e.g. Minde, 2005; Saarikivi, 2011). The Sámi languages have had to give way in large areas firstly due to Christianity and new cultures as early as the 1700 s and 1800 s. Secondly, in order to maintain traditional land, the Sámi people have become settlers, which also have also presumably contributed the language shift (Saarikivi, 2014). However, there is still major lack of research in Finland regarding the Sámi as- similation, although some scholars have highlighted local issues concerning language shift (Aikio, 1988).

Huss (1999) explains that in the modern world assimilation and revitalisation often happen side by side, so that there seems to be a contest between the two processes. This means that a language shift usually persists in spite of revitalisation. Rasmussen (2013) noted that even though revitalisation is underway in many communities, the language shift still continues in some form or other. An alternative to the language shift would be the establishment of language nests, and language revitalisation classes in locations where there is a need for them. Language nest means the certain kind of day care model where only the minority language is spoken. The aim of language nest is to protect endangered minority languages. (see e.g. Pasanen, 2015).

Depending on the starting point and the viewpoint of the research, the concept of language revitalisation can be explained in different ways. In general, revitalisation refers to measures aimed at preventing the language from dying out or slowing down the language loss (Fishman, 1991; Olthuis et al., 2013). According to Fishman (1991), language revitalisation is the systematic protection and revitalisation of language, with the main objective of increasing the number of language speakers and expanding the language domains. Such domains include, for example, the home, school, work, social media, other official contacts and friends. In addition, in order for language revitalisation to be successful, society must manifest a positive attitude towards the language needing to be revitalised (Fishman, 1991, 1999).

Helander (2009) notes that the aim of Sámi language revitalisation is to revive the Sámi languages in areas where their use is threatened. Further language revitalisation means to expand the domains of the Sámi languages or the use of language possibilities. In other words, language vitality is supported (Helander, 2009; Pasanen, 2003; Rasmussen, 2013; Todal, 2002, 2007, 2009). Huss (1999) suggests that revitalisation also means, for example, the older generation of people are learning their people's language and beginning to use it, or that people who have only been able to speak the language are learning to write it.

In other words, the revival of the language is not just down to individuals but also to entire communities. In order for language revitalisation to be successful, there should be support at both the community level as well as the individual level, in addition to the expansion of language domains. In Sámi homeland area, intergenerational language revitalisation has had considerable success with the Inari Sámi language (Pasanen, 2003).

\section{Mediating Structures in Revitalisation}

Mediation is a key objective of Sámi education and it is also particularly significant in multilingual and multicultural contexts. According to the Oxford American Writ- 
er's Thesaurus (Auburn et al., 2012), the word "mediate" means to arbitrate, make peace, resolve and negotiate. Berger (1979) defined the concept of mediating structures as "those institutions which stand between the individual in his [sic] private sphere and the large institutions of the public sphere" (p. 169). Mediation includes inclusion and caring, in addition to participatory and conclusive motives. From this perspective, mediation is a versatile concept.

Keskitalo (2010) proposed that through mediating structures it is possible to resolve a school's culture and any possible cultural conflicts. In the context of Sámi education, the colonial history and asymmetrical power relations have prevented the Sámi from forming their own school culture. According to Keskitalo (2010), the necessary mediating structures must take account of time, space and knowledge understanding so that the school timetables, space and knowledge are rethought and the Sámi knowledge system and values are placed at the core.

The concept of bundle mediating structures was proposed by Berger and Neuhaus (1970), who suggested that family culture and school culture should be compounded in order to empower the people. In other words, mediating structures are intercultural educational tools. Further, Nurmi and Kontiainen (1995) adapted the model so that the mediating structures could operate in an intercultural educational context. Generally, in an intercultural context, cultural conflict is inevitable. Mediating structures communicate between the past, the present and the future circumferentially. Families, neighbourhood groups, religious groups, and voluntary associations were mentioned in Johnson's (1994) research as mediating structures. For example, in multilingual and multicultural educational practice, cultural conflicts can arise due to asymmetric power connections (Keskitalo, 2010). The concept of the bundle mediating Sámi education has been developed on the basis of joint educational activities and research (Keskitalo et al., 2013; Keskitalo \& Sarivaara, 2014).

Aikio (2010) states that as Sámi education has been discoloured by the long history of assimilation, the most important Sámi educational goal is therefore the teaching of coping skills. In order to learn to cope, Sámi education aims for learners to be naturally helpful, peaceful, amicable, situation satisfied, curious in a familiar group, hardworking and imaginative (Aikio, 2010). These aspects have an inevitable impact on language revitalisation. Such revitalisation could therefore by further developed through education that relies on those personality aspects.

The mediating structures for language revitalisation require an awareness of socio-political and socioeconomic issues as well as attempts to actively resolve these factors rather than simply leave them be. Schools, family, society, media, friends and leisure facilities are all important factors when revitalising lan- guages. Schools may be ineffective at revitalisation by themselves, so other factors should also be invested. Ultimately, effective language revitalisation involves the following characteristics:

1. Adding new sets of speakers to the language, crucially involving the home domain and intergenerational transmission (King, 2009; Spolsky, 1989).

2. Adding new functions by introducing the language into domains where it was previously unused or relatively underused (Ó Laoire, 2006).

3. The language must be revived by both established speakers and neo-speakers (Huss, Grima, \& Kind, 2003).

4. Involvement and activity on behalf of individuals and the speech community as well as awareness that positive attitudes, action, commitment, strong acts of will and sacrifice may be necessary to save and revitalise the language (ó Laoire, 2006).

The objective of mediating structures is to reinforce cultural identity and indigeneity. Exclusionary models may lead to ethnocentric perspectives and, crucially, do not build a society that values pluralism and cultural diversity. Ethnocentrism is concept used for example in social science and education. William Graham Sumner (1906, p. 13) defines ethnocentrism as the view when one's own group is the centre and other groups are classified and assessed in relation to own group. According to our studies ethnocentrism does not empower indigenous peoples, but rather maintains essentialist paradigms. In addition, an ethnocentric perspective may trap individuals in the victim role, which in a collective context means that the group remains hindered by past discrimination. The victim role means that person feels him/herself unable to change his/her circumstances. It may bring negative discourse into communities and, in addition, it involves negative emotions such as scapegoating and seeing a future without hope. However, the victim role does tend to be one phase within indigenous peoples' consciousness raising and revitalisation processes. Indeed, traumatic experiences of the past should be grieved for and openly discussed within communities so that people are finally able to move on from them. However, the victim role may constitute a problematic base for discourse within indigenous peoples' communities. Also, essentialism and ethnocentrism may generate negative attitudes towards indigenous peoples. Minorities would benefit from constructing strategies that strengthen their minority position. Therefore, mediating structures are tools that aim to dismantle the asymmetric power structures. Educators and pedagogies play a core role in preventing phenomena that challenge society in several ways. Also, researchers in- 
volved with indigenous peoples' education are important in conducting practical measurements of language revitalisation.

\section{Obstacles and Facilities to Revitalisation}

There may occur many barriers and obstacles due to process of language revitalisation. However, there are also many possibilities that should be highlighted rather than just focusing on barriers. One of the major themes was raised by Sarivaara (2012), and concerns the question of who particularly is authorised to take part in language revitalisation. This leads to question: who is indigenous enough. Smith (1999/2012) argues that indigenous identity has often been based on a set of requirements concerning authenticity and essentialism. Moreover, the authenticity attributed to indigenous peoples is based on stereotypical perspectives on their culture. Thus, the images of culture are understood only narrowly. Hall (1999) states that when stereotyping, all of the named issues are going to be reduced to some simple characteristic, they are overstated and then all of the inappropriate stereotypes are excluded. The stereotypical model is not neutral, but instead shows the generally accepted and shared views of the social group. Ideas about social groups are often drawn from stereotypes (Hall, 1999). Essentialist identity understanding demonstrates an unchangeable, traditional and clear-cut view of identity. From this point of view, a person's identity remains the same throughout his/her life. For example, Sámi status has been understood as a gateway to revitalisation. In Finland, in some cases only those who are officially registered as Sámi in Sámi Parliament's electroral roll are able to take part in language revitalisation without questioning or excluding. There are numerous political and practical gatekeeper issues that may hamper language revitalisation (Sarivaara, 2012).

Sarivaara in her PhD research interviewed 15 individuals who have revitalised the Sámi language. These revivers of the Sámi languages are concerned about the future of the language and so are committed to promoting it. The study offers a new perspective on the discourse concerning Sámi identity and its boundaries. Sarivaara proposes that language support measures should be extended when revitalising; the threshold to participate in the language being revitalised should be lowered; and options should be widely offered. Further, investment must be made in motivational issues, the childhood language domain must be extended, language choices on a basis should be supported, and the possibilities for language study should be extended (Sarivaara, 2012). Every individual's background should be appreciated. It seems that there are lots of conflicts involved in language revitalisation. It is important to be aware of the psychological effect whereby a common background is assumed as part of the heritage of colonialism and assimilation. A lack of appreciation of Sámi languages in education and in society in general has caused a situation where feelings of shame hinder language revitalisation. In addition, there are also political, structural and practical hindrances that slow down and prevent language revitalisation. Also, the demand for a pure blood, official Sámi identity may be one of criteria for obtaining the privilege of revitalising the Sámi language. This means that an indigenous person's authenticity may be questioned. According to Smith (1999/2012), such questioning can prove hurtful, especially to individuals who already feel marginalised.

Keskitalo (2010) highlighted how multiple and demanding intercultural learning practices can be implemented in classrooms in Norway Sámi Schools. She suggests that Sámi knowledge, time and understanding of place should be integrated into the curriculum so as to better motivate both pupils and teachers (Keskitalo, 2010). Local values and localism are key due to multicultural and minority/indigenous schooling issues (Babaci Wilhite, 2015). After all, Sámi education is a highly diverse issue due to the history of assimilation. Pupils come from culturally different backgrounds, which also result in different identities and different worlds of experiences. The teacher's role includes supporting pupils' cultural identity, so there is a need to understand the complex and multiple phenomena of the cultural identity of both teachers and pupils (Banks, 2013). These aspects should therefore play a key role in education.

\section{Discussion}

The concept of mediating Sámi education involves instruments aimed at constructively resolving conflicts. In addition, it is an activity that strengthens emancipation. Education is based on caring and inclusive activities. Mediating Sámi education thus results in workable models for the resolution of conflicts. Among other things, such mediation of Sámi education is interested in how education can disassemble oblique and unequal connections between communities. Another important development measure involves looking at how we can strengthen the pedagogical research concerning mediating and inclusive indigenous identities. Several issues have become topical lately in the context of indigenous education and they will help to dismantle the heritage of assimilation (see Denzin, Lincoln, \& Smith, 2008).

The concrete issue that deserves the first priority is to solve constructively intern conflicts and oppression within Sámi society. For example, defaulting communication and poor management of internal conflict are part of the process of lateral violence, which is an expression of internalized colonialism. Internalized colonialism can be harmful for the indigenous society because it gets oppressed people to work against each other. Richard Frankland states, that: 
"[T]he organised, harmful behaviours that we do to each other collectively as part of an oppressed group: within our families; within our organisations and; within our communities. When we are consistently oppressed we live with great fear and great anger and we often turn on those who are closest to us". (Australian Human Rights Commission, 2011, p. 8)

Mediating structures should generate synergic connections within the revitalisation process. This basically means aiming to increase the synergy between different groups. Such synergy forms as a result of cooperation and extended networking. However, it demands tolerance, solidarity and the development of cultural identities. Language revitalisation in mediating education enables individual to construct and strengthen their cultural identity and language skills within a community characterised by a positive atmosphere and spirit. It is then possible that individuals are able to develop and flourish. In addition, practical language-related activities should be implemented as soon as possible, whether that means language nests for kindergarten children, primary school revitalisation language classes or adult revitalisation teaching. Societal support for plans, goals and economy is important, but individuals' own attitudes towards the revitalisation process are more important.

Empowerment, revitalisation, education and research are the core components of the transformation and future for indigenous peoples. Today, Sámi pupils are members the future society. It is necessary to explore what kind of Sámi society is desired, what kind of values are important, and what kind of issues should be changed. The objective of research is to identify oppressive and undignified issues, and also to try and solve them (see Suoranta \& Ryynänen, 2014). In addition, mediating structures corroborate human rights, which aim to include all peoples and involve them in the development of society. Language revitalisation benefits mediating structures, since it enforces individuals' language learning and hence increases language domains. Mediating structures also aim to tackle-at a societal level, practical macro and micro level, and an individual level-the complicated practical and psychological issues that may help or hinder language revitalisation. Research in this area would benefit from practical work with language revitalisation. Researchers and educators should thus work together to help language revitalisation to progress.

\section{Acknowledgments}

We are grateful to all the communities in which we have been able to carry out research work. We would like to thank both Sámi University College and University of Lapland giving resources to conduct research. Special thanks to joint PhD supervisor professor Kaari- na Määttä (University of Lapland) and dean Seija Risten Somby (Sámi University College) giving professional support.

\section{Conflict of Interests}

The authors declare no conflict of interests.

\section{References}

Afanasyeva, A. (2013). Forced relations of the Kola Sámi people: Background and consequences (Master of Philosophy in Indigenous Studies). Faculty of Humanities, Social Sciences and Education, University of Troms $\varnothing$, Troms $\varnothing$, Norway.

Aikio, A. (2004). An essay on substrate studies and the origin of Saami. In I. Hyvärinen, P. Kallio, \& J. Korhonen (Eds.), Etymologie, entlehnungen und entwicklungen: Festschrift für jorma koivulehto zum 70. Geburstag (pp. 5-34). Helsinki, Finland: Finno-Ugric Association.

Aikio, A. (2010). Sápmelaš bajásgeassin. Pedagogihka oahpahus giđđat 2010. Guovdageaidnu, Norway: Sámi allaskuvla.

Aikio, A. (2012). An essay on Saami ethnolinguistic prehistory. In R. Grünthal \& P. Kallio (Eds.), A linguistic map of prehistoric Northern Europe (pp. 69-117). Helsinki, Finland: Finno-Ugric Association.

Aikio, M. (1988). Saamelaiset kielenvaihdon kierteessä. Kielisosiologinen tutkimus viiden saamelaiskylän kielenvaihdosta 1910-1980. Helsinki, Finland: SKS.

Auburn, D., Armantrout, R., Crystal, D., Dirda, M., Garner, B., Ferris, J.,..., Zimmer, B. (Eds.). (2012). Oxford American writer's thesaurus (3rd ed.). Oxford, NY: Oxford University Press.

Australian Human Rights Commission. (2011). Social justice report 2011. Sydney, Australia: Australian Human Rights Commission. Retrieved from https:// www.humanrights.gov.au/sites/default/files/content /social_justice/sj_report/sjreport11/pdf/sjr2011.pdf

Babaci Wilhite, Z. (2015). Local languages as a human right in education. Comparative cases from Africa. Rotterdam: Sense Publishers.

Banks, J. A. (2013). Group identity and citizenship education. Global Times, Kappa Delta Pi Record, 49(3), 108112.

Battiste, M. (2000). Introduction: Unfolding the lessons of colonization. In M. Battiste (Ed.), Reclaiming indigenous voice and vision (pp. xvi-xxx). Vancouver, Canada: UBC Press.

Berger, P. L. (1979). In praise of particularism: The concept of mediating structures. In Facing up to modernity-Excursions in society, politics and religion (pp. 167-180). Middlesex, UK: Penguin Books.

Berger, P. L., \& Neuhaus, R. J. (1970). Movement and revolution. Garden City, NY: Doubleday.

Denzin, N. K., Lincoln, Y. S., \& Smith, L. T. (Eds.). (2008). 
Handbook of critical and indigenous methodologies. Thousand Oaks, USA: Sage.

Fanon, F. (1959). Studies in a dying colonialism. Harmondsworth: Penguin.

Fanon, F. (1961). The wretched of the earth. Harmondsworth: Penguin.

Fanon, F. (1967). Black skin, white masks. New York, NY: Grove Press. (Original work published 1952).

Fishman, J. A. (1991). Reversing language shift. Theoretical and empirical foundations of assistance to threatened languages. Bristol, UK: Multilingual Matters.

Fishman, J. A. (Ed.) (1999). Handbook of language and ethnic identity. New York: Oxford University Press.

Gilroy, P. (1993). 'Where ignorant armies clash by night': Homogeneous community and the planetary aspect. International Journal of Cultural Studies, 6(3), 261276.

Hall, S. (1999). Identiteetti (L. Mikko \& H. Juha, Trans.). Tampere, Finland: Vastapaino.

Helander, N. (2009). Samisk språk og samiske språkforhold: Med særlig vekt på nordsamisk. In T. Bull \& A.-R. Lindgren (Eds.), De mange språk i Norge. Flerspråklighet på norsk (pp. 125-140). Oslo, Norway: Novus.

Henrysson, S. (1992). Saami education in Sweden in the 1900's. In R. Kvisti (Ed.), Reading in Saami history, culture and language, III (pp. 103-110). Umeå, Sweden: Umeå University.

Huss, L. (1999). Reversing language shift in the far North. Linguistic revitalisation in Northern Scandinavia and Finland (Studia Uralica Upsaliensia 31). Uppsala, Sweden: Acta Universitatis Upsaliensis.

Huss, L., Grima, A. C., \& Kind, K. A. (Eds.). (2003). Transcending monolingualism: Linguistic revitalisation in education. Lisse, The Netherlands: Swets and Zeitlinger.

Johnson, V. R. (1994). Connecting families and schools through mediating structures. School Community Journal, 4(1), 311-318.

Keskitalo, P. (2010). Saamelaiskoulun kulttuurisensitiivisyyttä etsimässä kasvatusantropologian keinoin (PhD dissertation). Guovdageaidnu, Norway: Sámi allaskuvla.

Keskitalo, P., Lehtola, V.-P., \& Paksuniemi, M. (Eds.). (2014). Saamelaisten kansanopetuksen ja koulunkäynnin historia Suomessa. Turku, Finland: Siirtolaisuusinstituutti.

Keskitalo, P., \& Sarivaara, E. (2014). Välittävän saamentutkimuksen merkitys. In K. Määttä \& S. Uusiautti (Eds.), Voimaa välittävästä tutkimuksesta (pp. 55-64). Lapin yliopistopaino, Finland: Rovaniemi.

Keskitalo, P., Uusiautti, S., \& Määttä, K. (2013). Sámi Education. Frankfurt am Main, Germany: Peter Lang Edition.

King, J. (2009). Language is life. In J. Reyhner \& L. Lockard (Eds.), Indigenous language revitalisation: Encouragement, guidance \& lessons learned (pp. 97-
108). Flagstaff, AZ: Northern Arizona University.

Kuokkanen, R. (1999). Etnostressistä sillanrakennukseen. Saamelaisen nykykirjallisuuden minäkuvat. In $\mathrm{M}$. Tuominen, S. Tuulentie, V.-P. Lehtola, \& M. Autti (Eds.), Pohjoiset identiteetit ja mentaliteetit, osa I: Outamaalta tunturiin (pp. 95-112). Rovaniemi, Finland: University of Lapland.

Kuokkanen, R. (2007). Saamelaiset ja kolonialismin vaikutukset nykypäivänä. In J. Kuortti, M. Lehtinen, \& O. Löytty (Eds.), Kolonialismin jäljet: keskustat, periferiat ja Suomi (pp. 142-155). Helsinki, Finland: Gaudeamus. Retrieved from files.wordpress.com/ 2007/10/014_postkolo_kuokkanen.pdf

Lehtola, V.-P. (2012). Saamelaiset suomalaiset: Kohtaamisia 1896-1953. Helsinki, Finland: Suomalaisen Kirjallisuuden Seura.

Lindgren, A.-R. (2000). Helsingin saamelaiset ja oma kieli. Helsinki, Finland: SKS.

Linkola, I.-A. (2014). Saamelaisen koulun kielimaisema: Etnografinen tutkimus saamen kielestä toisen asteen oppilaitoksessa (PhD dissertation). Kautokeino, Norway: Sámi allaskuvla.

Minde, H. (2005). Sámiid dáruiduhttin-Manin, mo ja makkár váikkuhusat? In S. Lund, E. Boine, \& S. Broch Johansen (Eds.), Sámi skuvlahistorjá 1. Kárášjohka, Norway: Davvi girji. Retrieved from http://skuvla. info/skolehist/minde-s.htm

Nurmi, K. E., \& Kontiainen, S. (1995). A framework for adult learning in cultural context: Mediating cultural encounters. In A. Kauppi, S. Kontiainen, K. E. Nurmi, J. Tuomisto, \& T. Vaherva (Eds.), Adult learning in a cultural context (pp. 65-71). Helsinki, Finland: Lahti Research and Training Centre, Adult Education Research Society, University of Helsinki.

Ó Laoire, M. (2006). Language education for language revival. In K. Brown (Ed.), Encyclopedia of language and linguistics (Vol. 6, p. 407). Oxford, UK: Elsevier.

Ó Laoire, M. (2008). Indigenous language revitalisation and globalization. Te Kaharoa, 1, 203-216.

Olthuis, M.-L., Kivelä, S., \& Skutnabb-Kangas, T. (2013). Revitalising indigenous languages: How to recreate a lost generation. Bristol, UK: Multilingual matters.

Pasanen, A. (2003). Kielipesä ja revitalisaatio: Karjalaisten ja inarinsaamelaisten kielipesätoiminta (Master thesis, Itämeren suomalaiset kielet). Helsinki, Finland: Suomalais-Ugrilainen laitos, Helsingin yliopisto.

Pasanen, A. (2015). Kuávsui já peeivičuovâ. 'Sarastus ja päivänvalo'-Inarinsaamen kielen revitalisaatio (Uralica Helsingiensia, 9). Helsinki, Finland: Suomalais-Ugrilainen Seura.

Rasmussen, T. (2013). "Go ealáska, de lea váttis dápmat". Davvisámegiela etnoligvisttalaš ceavzinnávccaid guorahallan guovtti gránnjágielddas Deanus ja Ohcejogas 2000-logu álggus (PhD dissertation). Guovdageaidnu, Norway: Sámi allaskuvla. 
Saarikivi, J. (2011). Saamelaiskielet-Nykypäivää ja historiaa. In I. Seurujärvi-Kari, P. Halinen, \& R. Pulkkinen (Eds.), Saamentutkimus tänään (Tietolipas 234, pp. 77-119). Helsinki, Finland: Suomalaisen Kirjallisuuden Seura.

Saarikivi, J. (2014). Vähemmistökielten suojelu ja vähemmistökielinen koulutus saamelaiskontekstissa. In P. Keskitalo, V.-P. Lehtoja, \& M. Paksuniemi (Eds.), Saamelaisten kansanopetuksen ja koulunkäynnin historia Suomessa (pp. 341-350). Turku, Finland: Siirtolaisuusinstituutti.

Said, E. W. (1993). Culture and imperialism. New York: Vintage.

Sarivaara, E. K. (2012). Statuksettomat saamelaiset. Paikantumisia saamelaisuuden rajoilla (PhD dissertation). Guovdageaidnu, Norway: Sámi allaskuvla, University of Lapland.

Sarivaara, E. K. (in press). Emergent Sámi identities: From assimilation towards revitalisation. In R. Toivanen \& J. Saarikivi (Eds.), New and old language diversities. Bristol, UK: Multilingual Matters.

Sarivaara, E., \& Keskitalo, P. (2015). Fátmmasteaddji giellaealáskahttin. AGON, 1. Retrieved from http:// agon.fi/article/fatmmasteaddji-giellaealaskahttin

Seurujärvi-Kari, I. (2012). Ale jaskkot eatnigiella. Alkuperäiskansaliikkeen ja saamen kielen merkitys saamelaisten identiteetille. Helsinki, Finland: SKS.
Smith, L. T. (2012). Decolonizing methodologies: Research and indigenous peoples. London: Zed Books. (Original work published 1999)

Solbakk, J. T. (2006). Reindeer husbandry: An exclusive Sámi livelihood in Norway (L. Bennett, Trans.). Kautokeino, Norway: Resource Centre for the Rights of Indigenous Peoples. Retrieved from http://www. galdu.org/govat/doc/eng_reindeer.pdf

Spivak, G. C. (1985). Three women's texts and a critique of imperialism. Critical Inquiry, 12, 243-261.

Spolsky, B. (1989). Conditions for second language learning. Oxford: Oxford University Press.

Sumner, W. G. (1906). Folkways: A study of the sociological importance of usages, manners, and morals. Boston: Ginn and Company.

Suoranta, J., \& Ryynänen, S. (2014). Taisteleva tutkimus. Helsinki, Finland: Into Kustannus Oy.

Todal, J. (2002). "Jos fal gáhttet gollegielat": Vitalisering av samisk språk i Noreg på 1990-talet (PhD dissertation). Troms $\varnothing$, Norway: Troms $\varnothing$ University.

Todal, J. (2007). Samisk språk i Svahken sijte. Sørsamisk vitalisering gjennom barnehage og skule. Guovdageaidnu, Norway: Sámi Instituhtta.

Todal, J. (2009). Sørsamisk og lulesamisk. In T. Bull \& A.R. Lindgren (Eds.), De mange språk i Norge. Flerspråklighet på norsk (pp. 141-152). Oslo, Norway: Novus.

\section{About the Authors}

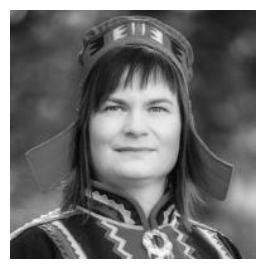

\section{Dr. Erika Sarivaara}

Erika Sarivaara is working as a Post-doctoral researcher at University of Lapland. Her research is about Inari Sámi Language and Sámi Giellatekno (Sámi Language Teknology) in cooperation with UiT Norwegian Arctic University at Troms $\varnothing$. She is interested in language sociology and education research within Sámi context.

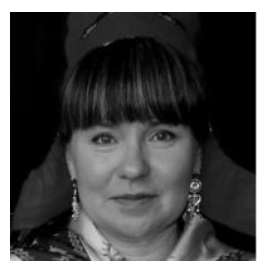

\section{Dr. Pigga Keskitalo}

Pigga Keskitalo is an Adjunct Professor at University of Helsinki, Finland, and Assistant Professor of Sámi University College, Norway. She is working with Sámi teacher training and multicultural education. 